\title{
PERAN NILAI KERJA EMPAT FAKTOR DAN KEPEMIMPINAN DENGAN KONTRAK PSIKOLOGIS SEBAGAI MEDIATOR TERHADAP TIM KERJA EFEKTIF
}

\author{
Rizki Fitlya \\ PT. Global Transportasi Nusantara, Jl. A.Yani Komp A.Yani Mega Mall Blok E-21 Pontianak \\ d2k_qq@yahoo.co.id
}

\begin{abstract}
This reserach aims to explore the role of work value factors, transactional dan transformational leadership type, psychological contract to team effectiveness and examined the variables that give significant contribution to team effectiveness. This research involved 170 of medical and non-medical employee in X Hospital, Pontianak. Effective team work scale, psychological contract scale, transformational and transactional leadership scale and work value survey were used to collect the data. Data was analyzed using Structural Equation Modeling (SEM) method trough AMOS Program. Result showed work value factors, transactional and transformational leadership type influence to team effectiveness with psychological contract as mediator variable. Psychological contract give a significant contribution to team effectiveness, therefore it could be predictor to team effectiveness.
\end{abstract}

Key word: psychological contract, team effectiveness, transformational leadership transactional leadership,

\begin{abstract}
Abstrak
Tujuan penelitian ini adalah untuk mengetahui peran-peran variabel nilai kerja empat faktor dan kepemimpinan tipe transformasional, tipe transaksional pada kontrak psikologi yang akan menyumbang pada tinggi rendahnya tim kerja efektif dan untuk mengetahui variabel mana yang memberikan sumbangan terbesar tim kerja efektif. Subjek penelitian adalah karyawan medis dan non medis RS X Pontianak dengan jumlah 170 orang. Data diperoleh melalui skala tim kerja efektif, skala kontrak psikologis, skala kepemimpinan tipe transformasionl dan tipe transaksional. Data terkait nilai kerja diperoleh melalui Work Value Survey. Data yang telah diperoleh dari responden kemudian diolah dengan pendekatan kuantitatif dan dianalisis dengan metode Structural Equation Modeling atau SEM menggunakan program Amos. Hasil penelitian menunjukkan ada peran nilai kerja faktor ekstrinsik, faktor instrinsik, faktor sosial, dan kepemimpinan tipe transformasional, tipe transaksional dengan mediator kontrak psikologis terhadap tim kerja efektif. Kontrak psikologis memiliki peran terbesar terhadap tim kerja efektif sehingga kontrak psikologis dapat digunakan sebagai alat prediktor terhadap tim kerja efektif.
\end{abstract}

kata kunci: kontrak psikologi, tim kerja efektif, tipe kepemimpinan transformasional, tipe kepemimpinan transaksional, 


\section{Pendahuluan}

Sebuah organisasi terdapat banyak tim kerja. Tim kerja adalah sebuah kelompok individu yang menghasilkan tingkat kinerja yang lebih besar dari pada jumlah masykan individu tersebut. Menurut Homans (Luthan, 2011) ketika bekerja dalam kelompok terdapat suatu proses interkasi antar anggotanya dalam mencapai tujuan bersama. Interaksi tersebut merupakan hubungan antar dua orang atau lebih (Hoegl \& Gemunden, 2001).Berdasar social exchange theory yang dikembangkan oleh Thibhaout dan Kelley (Luthan, 2011), interaksi yang positif dalam kelompok dapat meningkatkan keterkaitan dan afiliasi anggota yang berada didalamnya. Interaksi individu pada kelompok kerja dapat diartikan sebagai tim kerja (Lencini, 2005; Parker 2008). Secara garis besar komponen kerja tim yang memperoleh perhatian yang paling besar adalah kerjasama, kepercayaan dan kekompakan.

Berdasarkan wawancara awal yang dilakukan di Rumah Sakit (RS) X di Pontianak, masih terdapat beberapa masalah yang berkaitan dengan tim kerja efektif. Beberapa karyawan baik tenaga medis maupun non medis di RS X Pontianak merasa kurang adanya kerjasama antar sesama. Kurangnya komunikasi dan keinginan untuk saling terbuka seringkali menimbulkan konflik antar karyawan, tetapi ada beberapa karyawan yang belum bersedia membantu tugas rekan lainnya, karena sudah merasa memiliki tugas masingmasing. Kurangnya pertukaran informasi mengenai kondisi pasien, keluhan pasien, perkembangan pasien yang harus diketahui oleh perawat jaga dalam ruangan dirasakan oleh perawat masih kurang.

Berbagai masalah yang telah ditemukan dan dipaparkan diatas mengindikasikan adanya permasalahan yang berkaitan dengan rim kerja efektif pada karayawan di RS X Pontianak. Hasil kerja akan lebih optimal apabila para karyawan memiliki kemauan untuk bekerja secara tim untuk menyelesaikan pekerjaannya dengan tujuan yang sama.

Forsyth (2010) menyatakan bahwa suatu kerja tim yang baik akan terbentuk didalam tim yang efektif. Harris dan Harris (1996) menjelaskan bahwa kondisi tim yang efektif dapat tercapai jika anggota tim memiliki tujuan bersama, mampu mengembangkan hubungan yang efektif dan bermutu dalam mencapai tujuan, mampu menciptakan lingkungan yang kooperatif melalui sharing knowledge dan skill. Menurut Smith, Harvey,dan Millett (1998), bahwa terdapat delapan poin penting untuk pengembangan tim kerja efektif yaitu tujuan yang jelas, wewenang pengambilan keputusan, akuntabilitas dan tanggung jawab, kepemimpinan yang efektif, pelatihan dan pengembangan, penyediaan sumber daya, dukungan organisasi dan penghargaan untuk keberhasilan tim.

Lencioni (2005) menyatakan bahwa tim yang efektif akan terbentuk ketika para anggotanya memiliki komitmen terhadap tim, dapat diandalkan dan fokus pada penyampaian hasil. Beberapa peneliti juga menyatakan terdapat beberapa faktor yang mempengaruhi efektifitas suatu tim antara lain formasi tim (Early \& Mosakowski, 2000), struktur tim (Kuo, 2004), karateristik anggota tim (Barick \& Stewart, 2000) dan kepemimpinan (Schiminke \& Wells, 1999). Senior dan Swailes (2007) menyatakan beberapa aspek yang dapat mempengaruhi tim yang efektif dalam organisasi adalah tujuan tim, organisasi tim, iklim tim, hubungan interpersonal, komunikasi, komposisi, koordinasi tim dengan organisasi dan kepemimpinan.

Kepemimpinan didefinisikan sebagai 
proses individu mempengaruhi anggota kelompok lainnya untuk pencapaian tujuan kelompok maupun organisasi secara pasti (Greenberg dan Baron,2002). Terdapat dua konsep kepemimpinan yang didasari oleh teori kebutuhan atau motivasi Maslow yaitu transformasional dan transaksional (Robbins dan Timothy,2008).

Berdasarkan uraian diatas, dapat diaasumsikan bahwa tim kerja merupakan usaha kelompok untuk mencapai tujuan bersama, pemimpin memiliki peran yang cukup penting dalam mencapai tim kerja yang efektif. Pelayanan RS X perlu ditingkatkan,sehingga perlu diketahui faktor-faktor psikologis dalam pencapaian tujuan sehingga perlu ditelaah faktor mana yang paling berpengaruh terhadap tim kerja efektif melalui mediator kontrak psikologi dipengaruhi oleh kepemimpinan tipe transformasional, tipe transaksional dan nilai kerja empat faktor yaitu faktor ekstrensik, instrinsik, sosial dan prestige. Chambel dan Alcover (2011) menunjukkan bahwa kontrak psikologis memiliki hubungan dengan sikap dan perilaku karyawan dengan orientasi relasional yang lebih tinggi untuk kepuasan terhadap pekerjaan mereka. Kontrak relasional didasarkan pada sikap saling percaya antar karyawan dan sikap kesetian terhadap organisasi, sehingga tim kerja efektif dapat terwujud.
Kontrak psikologis didefinisikan oleh Rousseau (2000) sebagai harapan bersama yang dimiliki oleh pihak pimpinan dan karyawan, mengenai syarat, kondisi dan konsekuensi timbal balik. Keadaan psikologis dari pimpinan dan karyawan mengembangkan mental model, menentukan harapan dan panduan pola perilaku untuk hubungan kontraktual. Pada umumnya, pelanggaran kontrak psikologi membahas tentang sikap dan perilaku karyawan di tempat kerja setelah menyadari pelanggaran yang telah dilakukan. Sikap tersebut termasuk dalam kepuasan karyawan yang lebih rendah, komitmen organisasi berkurang, penurunan kinerja dan memiliki keinginan yang tinggi untuk keluar dari organisasi (Nisar, Saeed, dan Bukhari, , 2011). Tinggi rendahnya kontrak psikologis salah satunya dapat dipengaruhi oleh nilai kerja individu. Nilai kerja dapat didefinisikan sebagai kualitas yang orang inginkan dari pekerjaan yang mencerminkan korespondensi antara kebutuhan dan kepuasan (Matic, 2008).

Berikut ini merupakan kerangka konseptual mengenai hubungan antara variabel nilai kerja empat faktor, kepemimpinan tipe transformasional, tipe transaksional, kontrak psikologis sebagai variabel mediator terhadap persepsi tim kerja efektif adalah sebagai berikut: 


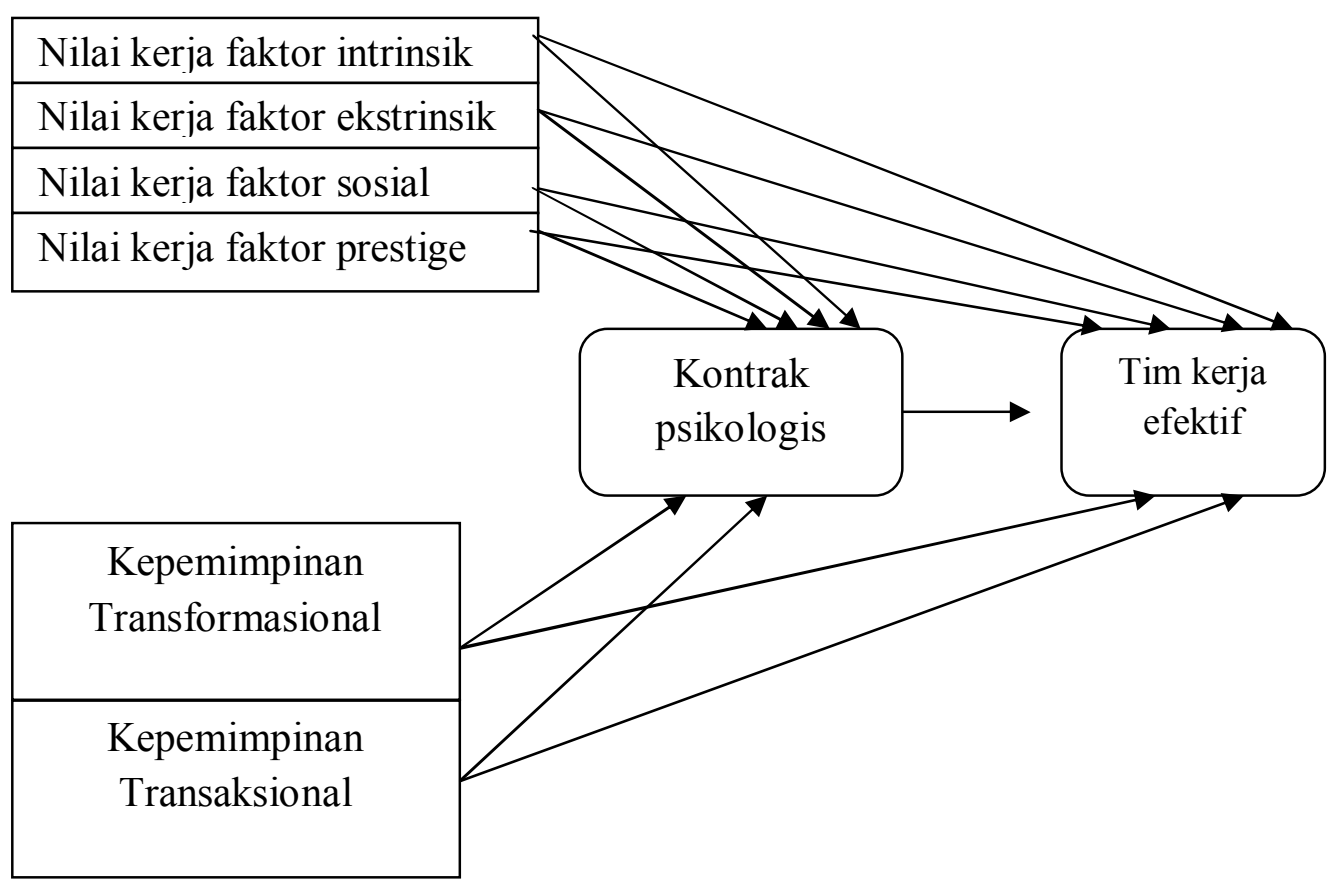

\section{Gambar 1. Peran nilai kerja empat faktor dan kepemimpinan tipe transformasional, tipe transaksional dengan kontrak psikologis sebagai intervening variabel terhadap tim kerja efektif.}

Berdasarkan pemaparan diatas, peneliti mengajukan hipotesis bahwa ada peran variabel-variabel nilai kerja empat faktor dan kepemimpinan tipe transformasional dan tipe transaksional pada mediator kontrak psikologi yang menyumbangkan pada tinggi rendahnyaa tim kerja efektif. Tujuan penelitian adalah untuk mengetahui peranperan variabel nilai kerja empat faktor dan kepemimpinan tipe transformasional, tipe transaksional pada kontrak psikologi yang akan menyumbang pada tinggi rendahnya tim kerja efektif dan untuk mengetahui variabel mana yang memberikan sumbangan terbesar tim kerja efektif

\section{Metode Penelitian}

Subjek penelitian adalah karyawan medis dan non medis RS X Pontianak dengan jumlah 170 orang, yang memiliki ciri bekerja dipelayanan medik, bekerja di layanan penunjang medik, bekerja dipelayanan dan penunjang umum dan karyaman yang memiliki atasan atau kepala ruang, selain itu subjek penelitian adalah karyawan yang aktif bekerja atau tidak sedang menjalani pendidikan, cuti dan sakit pada waktu penelitia dilakukan.

Penelitian ini menggunakan pendekatan kuantitatif dalam usaha menguji hipotesis yang telah disusun. Penelitian kuantitatif banyak dituntut menggunakan angka, mulai dari pengumpulan data, penafsiran terhadap angka tersebut, serta penampilan dari hasilnya, untuk itu peranan statistik dalam penelitian ini menjadi sangat dominan dan penting.

Data diperoleh melalui skala tim kerja efektif, skala kontrak psikologis, skala kepemimpinan tipe transformasionl dan tipe transaksional. Data terkait nilai kerja diperoleh melalui Work Value Survey. Data diperoleh menggunakan metode rating 
yang dijumlahkan dengan penskalaan model Likert. Data yang telah diperoleh dari responden kemudian diolah dengan pendekatan kuantitatif dan dianalisis dengan metode Structural Equation Modeling atau SEM menggunakan program Amos. Model struktural jalur secara teoritis dikembangkan berdasarkan variabel-variabel bebas yang berpengaruh nyata terhadap variabel terikat. Tahap selanjutnya data dianalisa dan diinterpretasikan dibuat laporan dengan sistematika yang telah ditentukan.

\section{Hasil dan Pembahasan}

Berdasarkan hasil analisis menunjukkan ada peran nilai kerja faktor ekstrinsik sebesar $23 \%$, nilai kerja faktor intrinsik sebesar 5\%, nilai kerja faktor sosial sebesar 9,1\%, kepemimpinan tipe transaksional sebesar 4,7\%, dan kepemimpinan tipe transformasional sebesar $4,8 \%$ pada mediator kontrak psikologis, sedangkan kontrak psikologis berperan terhadap tim kerja efektif sebesar $45,4 \%$.

Peran secara langsung, nilai kerja faktor sosial sebesar 4,5\%, nilai kerja faktor prestige sebesar 2,8\%, kepemimpinan tipe transaksional sebesar 4,8\%, dan kepemimpinan tipe transformasional sebesar 4\% terhadap peningkatan tim kerja efektif. Dari hasil diketahui bahwa pada model persamaan ini ditemukan peran kontrak psikologis sebagai mediator terhadap tim kerja efektif sebesar 45,4\% menunjukkan kuat sehingga dapat digunakan sebagai alat prediktor terhadap tim kerja efektif.

Setelah analisis terhadap overall model dan measurement model didapatkan hasil, maka langkah selanjutnya dapat dilakukan pengujian hipotesis. Pengujian hipotesis ini adalah dengan menganalisis nilai Critical Ratio (CR) dan nilai Probability (P) hasil olah data, dibandingkan dengan batasan statistik yang diisyaratkan, yaitu diatas 1,96 untuk nilai $\mathrm{CR}$ dan dibawah 0,05 untuk nilai $\mathrm{P}$ (probabilitas), jika hasil olah data menunjukkan nilai yang memenuhi syarat tersebut, maka hipotesis penelitian yang diajukan dapat diterima. Berdasarkan hasil analisis Structural Equation Modelling (SEM) dengan menggunakan bantuan program computer AMOS version 21,0 akan disajikan pada tabel 1 . 
Tabel 1:

Standardized Regression Weights

\begin{tabular}{|c|c|c|c|c|c|c|c|}
\hline Variabel & Pengaruh & Variabel & $\beta /$ koef & r2 & C.R & $\mathbf{P}$ & Ket \\
\hline $\begin{array}{l}\text { Kontrak } \\
\text { psikologis }\end{array}$ & $\leftarrow---$ & K.Transaksional & 0.216 & 0.047 & 2.724 & 0.006 & Sig \\
\hline $\begin{array}{l}\text { Kontrak } \\
\text { psikologis }\end{array}$ & $\leftarrow---$ & $\begin{array}{c}\text { K. } \\
\text { Transformasional }\end{array}$ & 0.218 & 0.048 & 2.742 & 0.006 & Sig \\
\hline $\begin{array}{l}\text { Kontrak } \\
\text { Psikologis }\end{array}$ & $\leftarrow---$ & Sosial & 0.302 & 0.091 & 2.976 & 0.003 & Sig \\
\hline $\begin{array}{l}\text { Kontrak } \\
\text { Psikologis }\end{array}$ & $\leftarrow---$ & Ekstrinsik & 0.480 & 0.230 & 4.641 & 0.000 & Sig \\
\hline $\begin{array}{l}\text { Kontrak } \\
\text { Psikologis }\end{array}$ & $\leftarrow---$ & Intrinsik & 0.224 & 0.050 & 2.257 & 0.024 & Sig \\
\hline $\begin{array}{l}\text { Kontrak } \\
\text { Psikologis }\end{array}$ & $\leftarrow---$ & Prestige & 0.066 & 0.004 & 0.919 & 0.358 & $\begin{array}{l}\text { No } \\
\text { sig }\end{array}$ \\
\hline $\begin{array}{l}\text { Tim Kerja } \\
\text { Efektif }\end{array}$ & $\leftarrow---$ & Sosial & 0.212 & 0.045 & 2.416 & 0.016 & Sig \\
\hline $\begin{array}{l}\text { Tim Kerja } \\
\text { Efektif }\end{array}$ & $\leftarrow---$ & Ekstrinsik & 0.088 & 0.008 & 1.039 & 0.299 & $\begin{array}{l}\text { No } \\
\text { sig }\end{array}$ \\
\hline $\begin{array}{l}\text { Tim Kerja } \\
\text { Efektif }\end{array}$ & $\leftarrow---$ & Intrinsik & 0.154 & 0.024 & 1.790 & 0.073 & $\begin{array}{l}\text { No } \\
\text { sig }\end{array}$ \\
\hline $\begin{array}{l}\text { Tim Kerja } \\
\text { Efektif }\end{array}$ & $\leftarrow---$ & Prestige & 0.167 & 0.028 & 2.613 & 0.009 & Sig \\
\hline $\begin{array}{l}\text { Tim Kerja } \\
\text { Efektif }\end{array}$ & $\leftarrow---$ & K.Transaksional & 0.220 & 0.048 & 3.126 & 0.002 & Sig \\
\hline $\begin{array}{l}\text { Tim Kerja } \\
\text { Efektif }\end{array}$ & $\leftarrow---$ & $\begin{array}{c}\text { K. } \\
\text { Transformasional }\end{array}$ & 0.200 & 0.040 & 2.863 & 0.004 & Sig \\
\hline $\begin{array}{l}\text { Tim Kerja } \\
\text { Efektif }\end{array}$ & $\leftarrow---$ & $\begin{array}{c}\text { Kontrak } \\
\text { psiokologis }\end{array}$ & 0.674 & 0.454 & 3.793 & 0.000 & Sig \\
\hline
\end{tabular}

Berdasarkan hasil analisis data, penelitian ini menunjukkan bahwa nilai kerja dengan faktor sosial, ekstrinsik dan intrinsik memiliki peran yang signifikan terhadap kontrak psikologi, namun faktor ekstrinsik memiliki peran yang lebih tinggi terhadap peningkatan kontrak psikologis. Karyawan membutuhkan adanya keamanan, ketertiban dan kondisi kerja yang baik dalam pekerjaan mereka serta pendapatan yang sesuai dengan kebutuhan mereka. Temuan tersebut sesuai dengan penelitian yang dilakukan oleh Lance, Hoffman, Campble dan Twenge (2010) dengan judul "perbedaan generasi didalam nilai kerja: kenyamanan dan meningkatkan nilai ekstrinsik, sosial dan menurunnya nilai intrinsik", menyatakan bahwa generasi pada saat ini lebih menekankan pada waktu luang dan menempatkan nilai kerja yang menyediakan imbalan ekstrinsik. Generasi pada saat ini juga menghargai nilai intrinsik dan penghargaan sosial dibandingkan dengan generasi sebelumnya.

Aspek tertinggi dari kontrak psikologis yaitu aspek kontrak transisional adanya perubahan organisasi yang bertentangan dengan pengaturan kerja sebelumnya. Perubahan tersebut menimbulkan rasa tidak aman dan kondisi yang tidak nyaman pada karyawan karena perubahan yang terjadi 
kurang sesuai atau bertentangan dengan pengaturan kerja yang telah ditetapkan sebelumnya. Karyawan jika sudah merasa keamanan kerja serta pendapatannya dirasa kurang sesuai dengan yang mereka harapkan maka yang terjadi adalah kepuasan karyawan menjadi lebih rendah, komitmen organisasi berkurang, penurunan kinerja dan memiliki keinginan yang tinggi untuk keluar dari organisasi (Nisar, Saeed dan Bukhari, 2011).

Kontrak transaksional merupakan aspek tertinggi kedua dari kontrak psikologis, hal tersebut menunjukkan bahwa karyawan di rumah sakit menginginkan pengaturan kerja yang yang berdasarkan reward, sehingga sejalan dengan nilai kerja faktor ekstrinsik yang berperan lebih besar terhadap kontrak psikologis. Menurut Grimmer dan Oddy (2007), bahwa karyawan dengan orientasi transaksional kemungkinan lebih besar bersifat jangka pendek dan cenderung memiliki keterlibatan yang kurang dekat dengan pimpinan, asalkan pertukaran ekonomi tidak terganggu.

Pada penelitian ini kepemimpinan tipe tranformasional dan kepemimpinan tipe transaksional juga memiliki peran yang siginifikan terhadap kontrak psikologis. Menurut Bycio, O'Shea, Foti, dan Hauenstain (2009), secara umum para pemimpin secara optimal efektif menggunakan kombinasi transformasional dan kontingen reward. Penelitian lainnya dari Smith dan Bell (2011) mengenai kepemimpinan transformasional dan transaksional di sekolah menunjukkan bahwa pimpinan menggunakan kedua pendekatan kepemimpinan, mereka percaya bahwa kepemimpinan transformasional jauh lebih efektif dalam mewujudkan perubahan yang menghasilkan pengembangan sekolah yang sukses, namun tekanan eksternal menyebabkan pimpinan lebih berkonsentrasi pada kepemimpinan transaksional.
Aspek yang tinggi pada kepemimpinan tipe transformasional adalah aspek motivasi inspirasional dan pengaruh ideal. Pemimpin berusaha membangkitkan motivasi karyawan dengan identifikasi pada perilaku pimpinan serta berusaha mengkomunikasikan visi menarik, menggunakan simbol-simbol untuk memfokuskan upaya bawahan dan melakukan pemodelan perilaku yang tepat.

Aspek yang paling tinggi pada kepemimpinan tipe transaksional adalah aspek manajemen aktif dengan pengecualian yakni pimpinan menggunakan hukuman kontingen dan tindakan korektif lainnya dalam menanggapi penyimpangan yang terjadi. Kepemimpinan tipe transformasional memiliki pengaruh yang lebih besar terhadap kontrak psikologis daripada kepemimpinan tipe transaksional. Karyawan di Rumah Sakit X menginginkan kepemimpinan yang sifatnya intrinsik yaitu memimpin dengan inspirasi dan merangsang bawahannya dengan memotivasi untuk memfokuskan upaya bawahan dan melakukan pemodelan perilaku yang tepat.

Kontrak psikologis memiliki peran yang signifikan terhadap peningkatan tim kerja efektif. Kontrak psikologis berhubungan langsung dengan aspekaspek yang ada di tim kerja efektif, dengan tingginya kontrak psikologis antara pimpinan dan karyawan terhadap organisasi, maka karyawan memiliki kemauan untuk menjunjung tinggi nilai-nilai yang telah disepakati bersama. Karyawan mau melakukan kerjasama, saling percaya dan saling membantu antara satu dengan lainnya dalam sebuah tim kerja dalam mencapai tujuan bersama. Hal tersebut sesuai dengan penelitian yang dilakukan Chambel dan Alcover (2011) menunjukkan bahwa kontrak psikologis memiliki hubungan dengan sikap dan perilaku karyawan dengan orientasi relasional yang lebih tinggi untuk 
kepuasan terhadap pekerjaan mereka. Kontrak relasional didasarkan pada sikap saling percaya antar karyawan dan sikap kesetian terhadap organisasi, sehingga tim kerja efektif dapat terwujud.

Kontrak psikologis sebagai intervening variabel memiliki sumbangan terhadap tim kerja yaitu sebesar 45,4\%. Kontrak psikologi mendasarkan pada kepemimpinan yang sifatnya intrinsik yaitu kepemimpinan tipe transformasional, dan diwarnai dengan nilai kerja ekstrinsik yang tinggi namun faktor intrinsik dan sosial masih berperan. Karyawan di rumah sakit menginginkan dan mengharapkan kepemimpinann yang mengajak untuk kerjasama dan yang membawa kebersamaan serta dilatar belakangi oleh nilai kerja yang mengekspresikan nilai-nilai konservasi, keamanan pekerjaan dan pendapatan dengan menyediakan pekerja persyaratan yang dibutuhkan untuk keamanan umum dan pemeliharaan ketertiban dalam kehidupan mereka. Karyawan juga mengejar kemandirian, pertumbuhan dan kreativitas dalam pekerjaan serta membutuhkan hubungan sosial.

Nilai kerja dengan faktor sosial dan prestige memiliki peran yang signifikan terhadap tim kerja efektif secara langsung. Hal ini menunjukkan bahwa karyawan memandang pekerjaannya sebagai kendaraan untuk hubungan sosial yang positif dan menunjukkan bahwa karyawan mengekspresikan nilai-nilai kedudukan, pujian dan penghargaan di dalam organisasi. Aspek kohesivitas yang tinggi pada tim kerja efektif berarti adanya rasa kebersamaan atas dasar saling ketergantungan yang dibutuhkan untuk mencapai tujuan dari pekerjaan. Hal ini menunjukkan bahwa dengan adanya kebutuhan akan hubungan sosial yang baik maka karyawan menciptakan rasa kebersamaan atas dasar saling ketergantungan dalam pencapaian tujuan tim.

Kepemimpinan tipe transformasional dan tipe transaksional memiliki peran yang signifikan terhadap tim kerja efektif. Kepemimpinan merupakan salah satu aspek yang memiliki peran yang dominan dalam pembentukan tim kerja efektif. Kohesivitas, kerjasama dan kepercayaan yang tinggi dibutuhkan dalam tim kerja sehingga tujuan tim dapat tercapai sesuai dengan diharapkan. Menurut Hoyt dan Blascovich (2003), sebuah kelompok kerja memiliki kinerja kuantitatif lebih besar dibawah pimpinan transaksional tetapi kinerja kualitatif unggul di bawah pimpinan transformasional.

Kepemimpinan tipe transaksional memiliki pengaruh yang lebih besar terhadap tim kerja efektif daripada kepemimpinan tipe transformasional, sehingga untuk menciptakan tim kerja efektif, pimpinan menekankan pemberian hadiah atau reward kepada bawahannya namun tidak membangkitkan antusiasme dan komitmen karyawan terhadap pekerjaannya. Hal ini menyatakan bahwa karyawan di Rumah Sakit X Pontianak lebih menyukai tipe transaksional dalam mewujudkan tim kerja efektif. Berdasarkan penelitian yang dilakukan Ceri-Booms (2012) menunjukkan bahwa kepemimpinan transaksional memiliki hubungan positif dengan kepercayaan pada pemimpin dan hubungan ini dihubungkan oleh kepemimpinan otentik. Hasil ini juga mengidentifikasi perilaku kepemimpinan transaksional otentik yang menimbulkan kepercayaan pengikut.

Pengaruh secara langsung, tim kerja efektif berdasarkan pada kepemimpinan yang sifatnya ekstrinsik yaitu kepemimpinan tipe transaksional dan diwarnai dengan nilai kerja sosial dan prestige. Menurut Smith, Harvey dan Millet (1998), bahwa terdapat delapan poin penting untuk pengembangan 
tim kerja efektif yaitu tujuan yang jelas, wewenang pengambilan keputusan, akuntabilitas dan tanggung jawab, kepemimpinan yang efektif, pelatihan dan pengembangan, penyediaan sumber daya, dukungan organisasi dan penghargaan untuk keberhasilan tim. Kepemimpinan di rumah sakit X Pontianak masih menggunakan cara menekankan pemberian hadiah atau reward kepada bawahannya untuk mencapai tim kerja efektif. Nilai kerja sosial pada karyawan merupakan bentuk dari karakteristik sifat altruisme, namun sifat suka menolong tersebut didasari oleh faktor prestige yaitu mengharapkan pujian dan penghargaan.

Berdasarkan hasil kategorisasi diperoleh data secara keseluruhan bahwa sebanyak 79 subjek penelitian berada pada kategori sedang untuk variabel tim kerja efektif, artinya bahwa subyek merasa bahwa upaya mereka sudah cukup untuk mencapai tim kerja efektif, mereka merasa sudah mampu melakukan kerjasama, memiliki kemampuan, kemampuan untuk saling percaya dalam bekerja dan saling terikat satu sama lain dalam sebuah tim kerja. Kontrak psikologis pada penelitian ini juga dipersepsi oleh 93 subjek pada kategori sedang artinya bahwa adanya keyakinan dan harapan dari karyawan terhadap pimpinan mengenai suatu kondisi, timbal balik terhadap perusahaan dan saling menguntungkan. Pada variabel nilai kerja sebanyak 79 subjek berada pada kategori sedang, artinya bahwa adanya keyakinan yang diinginkan oleh karyawan mengenai kebutuhan dan kepuasan diantaranya kebutuhan akan rasa aman, penghasilan atau pendapatan yang sesuai dengan kebutuhan yang diharapkan, kebutuhan akan aktualisasi diri, mengejar kemandirian, pertumbuhan dan kreativitas dalam pekerjaan, kebutuhan akan hubungan social yang positif serta kebutuhan untuk mengekspresikan nilai-nilai kedudukan, pujian dan penghargaan.

Variabel kepemimpina tipe transformasional dipersepsi sebanyak 75 subyek pada kategori sedang, artinya tipe pimpinan memimpin dengan inspirasi dan merangsang bawahannya dengan memotivasi untuk membangkitkan antusiasme dan komitmen karyawan terhadap pekerjaan, sedangkan variabel kepemimpinan tipe transaksional dipersepsi sebanyak 84 subjek pada kategori sedang yang berarti pimpinan menekankan pada pemberian hadiah atau reward terhadap bawahannya untuk memotivasi. Tipe kepemimpinan yang lebih tinggi adalah kepemimpinan tipe transaksional yang berarti bahwa pimpinan di rumah sakit X Pontianak lebih menggunakan pemberian reward atau pemberian hadiah untuk meningkatkan motivasi demi pencapaian tujuan rumah sakit.

Berdasarkan temuan tersebut diatas menjadi dasar bahwa pada model persamaan ini, kontrak psikologis sebagai intervening memiliki peran terhadap peningkatan tim kerja efektif, dengan demikian kontrak psikologis dapat dipakai sebagai alat prediktor utama.

\section{Simpulan}

Berdasarkan hasil penelitian dapat disimpulkan bahwa ada peran nilai kerja faktor ekstrinsik, faktor instrinsik, faktor sosial, dan kepemimpinan tipe transformasional, tipe transaksional dengan mediator kontrak psikologis terhadap tim kerja efektif. Kontrak psikologis memiliki peran terbesar terhadap tim kerja efektif sehingga kontrak psikologis dapat digunakan sebagai alat prediktor terhadap tim kerja efektif. 


\section{Daftar Pustaka}

Bycio, P., O'Shea, P. G., Foti, R. J., \& Hauenstein, N. M. A. (2009). Are the best leaders both transformasional and transactional? A pattern-oriented analysis. Leadership Journal, 5, 237258.

Ceribooms, M. (2012). How Can authentic leaders create organizational identification? An empirical study on turkish employees. International Journal of Leadership Studies, 7, 172190.

Chambel, M. J., \&Alcover, C. M. (2011). The psychological contract of call-centre workers: Employment conditions, satisfaction and civic virtue behaviors. Journal Economic and Industrial Democracy, 32(1), 115-134.

Grimmer, M., \& Oddy, M. (2007). Violation of the psychological contract: the mediating effect of relational versus transaksional beliefs. Australian Journal of Management, 32, 153-174.

Hoyt, C.L., \& Blascovich, J. (2003). Transformational and transactional leadership in virtual and physical environments. Small Group Research, 34, 678-715.

Lance, C. E., Hoffman, B. J., Campbell, S. M., \& Twenge, J. M. (2010).
Generational differences in work values: leisure and extrinsic values increasing, social and intrinsic values decreasing. Journal of Management, 36(5), 1117-1142.

Nisar, M., Saeed, M. M., \& Bukhari, T. A. S. (2011). The effects of psychological contract breach on various employee level outcomes: The moderating role of islamic work ethic and adversity quotient. African Journal of Business Management, 5(21), 8393-8398.

Rousseau, D.M (2000. Psychological Contract Inventory Technical Report. Pennsylvania. Heinz Scholl of Public Policy and Graduate School of Industrial Administration Carnegie: Mellon University.

Smith, P., \& Bell, L. (2011). Transactional and transformasional leadership in schools in challenging circumstances: A policy paradox. Journal Management in Education, 25(2), 58-61.

Smith, D., Harvey, S \& Millett, B. (1998). Developing successful teams in organisations. Australian Journal of Management \& Organisational Behavior, 1(1), 1-8.

Yukl, G. (2006). Leadership in organizations. USA: Pearson Prentice Hall. 